\title{
15. PHYSICAL PROPERTIES MEASUREMENTS AND TEST PROCEDURES FOR LEG 27
}

\author{
Karl Rocker, Civil Engineering Laboratory, NCBC, Port Hueneme, California
}

\section{INTRODUCTION}

Measurements of density, porosity, and sound velocity presented in the Leg 27 Site Reports have commonly been called "physical properties" of the materials on which the measurements have been made. This is somewhat of a misnomer, for the value measured is not a property of the material, but is a property of that material at the state in which it exists when the test is being made. The degree to which these measurements represent the in situ condition is dependent on the accuracy of the testing method and the changes which have taken place in the material due to removal from its natural environment. Traditionally, physical properties data reported in the Initial Reports of the Deep Sea Drilling Project have been measured values and not in situ values which have been backfigured from the measurements. Leg 27 data are likewise measured values.

\section{GRAPE DENSITY AND POROSITY}

The Gamma Ray Attenuation Porosity Evaluator (GRAPE) has been onboard since Leg 1, and its use in the Deep Sea Drilling Program is described by Boyce (1973b). The equipment is more thoroughly described by Evans (1965) and evaluated by Harms and Choquette (1965). During Leg 27 the GRAPE was used to determine bulk-wet density of core sections prior to their being cut in half and of individual chunks of material removed from the core liner.

Density is determined by placing the sample in the path of a gamma-ray beam of known intensity and measuring the attenuation of the beam. The attenuation is primarily a function of sample thickness and the material attenuation coefficient, which is approximately the same for most minerals encountered. However, the coefficient for water is slightly higher, and reduction of raw gamma-ray counts requires that water content of the material be known. Several iterations of the procedure for computing density then backfiguring water content provide sufficient accuracy to obtain final GRAPE density.

The 150-cm-long core sections are "GRAPE'd" immediately after the core has been retrieved and sectioned. During Leg 27, less than half of the cored sediments were GRAPE'd due to time restrictions and obvious disturbance in some of the sections. Most basalt specimens recovered were not GRAPE'd. Aluminum and water standards are used to calibrate the device prior to testing each core. After the standards are run the core sections are passed through the gamma ray beam at $1.625 \mathrm{~mm} / \mathrm{sec}$. This rate, the beam diameter, and the data sampling rate limit resolution of the GRAPE to about $1.0 \mathrm{~cm}$ of travel. In other words, a layer of material would have to maintain constant density and diameter for at least $1.0 \mathrm{~cm}$ of core before the GRAPE reading would stabilize at a value reflecting that density. (However, unless the layer is at least several times that thickness, it is difficult to establish the stabilized level due to other fluctuations of the output trace.)

GRAPE density has traditionally been presented at core and site summary levels, and as such, accounts for a tremendous volume of data. Caution should be exercised in the use of these data because of a number of test-related factors which influence what the GRAPE is measuring. (This is not related to accuracy of the GRAPE system to determine density, felt to be sufficient for DSDP purposes.) Three of the more important factors are (1) most of the material GRAPE'd is so highly disturbed that its measured density is not indicative of in situ density; (2) cores of stiff sediment or rock often do not fill the liner but have low-density slurry or air voids within the zone tested; and (3) it is often easier to abstract incorrect values than correct values from the computerized plots of GRAPE data presented in the Initial Reports. A good understanding of GRAPE mechanics and of what data are actually shown in DSDP volumes is necessary for quantitative use of the information. Such an understanding is not widespread, and most Initial Reports do not provide sufficient explanation or caution on the subject. If density (or porosity) data are to be abstracted from the Initial Reports, the discussion of problems presented by Boyce (1973b) should be considered.

Most problems in use of GRAPE data can be eliminated by examining the core photographs. High disturbance and partially filled cross-sections are easily identified. GRAPE data from those areas of high disturbance should not be considered representative, as density is often lowered through mixing of undisturbed sediment with water and slurry. A correction to GRAPE density shown on the core summaries must be made where undisturbed material does not fill the core liner. To make this "diameter correction," the following formula is used (after Boyce, 1973b, with symbol changes).

$$
\gamma=\frac{100 \gamma_{A}-\gamma_{S} x}{100-x}
$$

where

$\gamma=$ wet-bulk density of undisturbed sediment or rock after diameter correction;

$\gamma_{A}=$ apparent wet-bulk density measured by the GRAPE without diameter correction;

$\gamma_{S}=$ Wet-bulk density of slurry filling the area between sediment and liner; and 
$x=$ the percentage of liner diameter taken up by the slurry.

To make this correction, slurry density and the undisturbed sediment diameter must be obtained. If these were not measured in the sediment laboratory (during Leg 27 it was considered to consume too much time), they can be estimated. The diameter may be measured from Initial Report core photographs, which are usually of sufficient clarity. (The scale shown beside the photographs is used to measure split core diameter. The core liner diameter is taken as $6.61 \mathrm{~cm}$, although it may appear to be larger due to distortion of the plastic after section splitting.) Slurry density is estimated at 1.2 $\mathrm{kg} / \mathrm{cm}^{3}$, the density of the drilling mud.

In the Leg 27 presentation all reduced data have been shown on the core summary level, except for voids and changes not indicative of a change in sediment density. On the site-summary level, only GRAPE data from relatively undisturbed materials are shown. The Site Reports also reflect diameter corrections.

Porosity determined from the GRAPE shares all computational procedures necessary to determine GRAPE bulk-wet density and is directly dependent on grain density for its accuracy. Once bulk-wet density has been calculated, grain density and the assumption of $100 \%$ saturation determine porosity. Porosity can be obtained from the GRAPE trace presented at the core level by use of the variable grain density scale. Porosity is read off the scale at the grain density level determined from sediment mineralogy. GRAPE porosity plotted at the site-summary level are from relatively undisturbed materials and reflect diameter corrections.

\section{WATER-DISPLACEMENT DENSITY}

Bulk-wet density at Sites 260 through 263 was also determined by weighing sample chunks in air and submerged in fresh water. Density was computed by dividing the weight of a sample in air by its volume, calculated from the difference between weight in air and weight in water. An Ohaus Cent-O-Gram balance was modified with an improvised cradle for the submerged weight. This equipment had only recently been brought onboard and has not been previously used during a DSDP cruise. Its use increased as Leg 27 progressed when it became apparent that precision was excellent.

The balance was used in the sedimentology lab and did not appear to be significantly affected by moderate variations in the generally good sea conditions encountered. Balance capacity is $311 \mathrm{~g}$ with scale increments down to $0.01 \mathrm{~g}$ on the front beam. Initially only chunks of heavily consolidated or lithified sediments were tested. The samples were kept moist to maintain a saturated surface without free water. Flaking or decomposition of the blocks when submerged affected only a few tesis and was readily apparent. At Sites 262 and 263 density of soft clay and ooze specimens was also measured.

A test series was run to estimate the ability of this water-displacement method to repeat measuréments on objects of known or constant density. Density of the same steel and brass objects was measured 18 times from Site 260 to Site 263. Density of the steel wrench-head used averaged $7.84 \mathrm{~g} / \mathrm{cc}$ and varied up to $0.67 \%$ with a standard deviation of $0.20 \%$. For the brass washers used, density averaged $8.55 \mathrm{~g} / \mathrm{cc}$, and varied up to $0.78 \%$ with a standard deviation of $0.21 \%$. True density of the objects is not known, but both the determined averages are within the range of published values for commercial brass and steel.

In another test series, the ability of specimen chunks to survive the process of being submerged in water for a wet-weight determination was tested. At Site 263, waterdisplacement density measurements were repeated for 26 specimens. The specimens were weighed in air and in water, and then those measurements were repeated. Density in the second determination ranged from $0.21 \%$ greater to $0.67 \%$ less than in the first test, with a standard deviation of $0.17 \%$. All but 4 of the 26 second measurements decreased in volume. Examination of the measurements shows a minute drop of weight in air and a proportionally larger drop in the submerged weight. This may be attributed to loss of some material during the submerged process with slight softening or expansion of the sediment chunk surface.

The water-displacement process was considered to be the most accurate means to determine bulk-wet density during Leg 27. It was used as a basis for site-summary profiles when other density determinations were in conflict. Direct comparison of water-displacement density is possible with GRAPE and syringe values in some instances, and these are discussed in a later section.

\section{SECTION WEIGHT DENSITY}

Average density for a section was determined from its weight prior to the GRAPE test and the known volume inside the section liner. Minor variations in internal core liner diameter were neglected. The procedure was followed to present a profile of its results at Site 259, then was discontinued for subsequent sites. Although the ability of this method to determine average section density is probably quite good due to the size of the sample, that density has little meaning. It is an average of disturbed and undisturbed sediments, slurry, and voids or inclusions of high density. No section contained the necessary $100 \%$ undisturbed and uniform sediment necessary to yield useful data.

\section{SHORE-LABORATORY DENSITY}

As a check on shipboard densities, cylindrical samples were taken in firm material for determination of density at the Navy's Civil Engineering Laboratory (CEL). The small plastic sampling cylinders, commonly used in the ship sedimentology laboratory, were filled with material from the center of the split core in an area of relatively low disturbance. The cylinder was pushed into the soil until the core liner was reached. The bottom 0.2 or 0.3 $\mathrm{cm}$ of sediment was extruded, sliced off, and discarded. This procedure was followed until the sampler was filled with material from the center of the core. It was then placed inside a plastic container with a snap-on lid, and sealed with electrician's tape. This was placed inside a second plastic container with a few drops of seawater and stored with other samples under refrigeration. On 
shore, the sample was extruded and weighed and its volume determined from cylinder dimensions and by a Beckman Model 930 air-compression pycnometer.

Shore density tests were discontinued after Site 260 when it became apparent that the triple beam balance was sufficiently accurate to weigh small samples and determine volume.

\section{SYRINGE POROSITY, DENSITY, AND WATER CONTENT}

Porosity, density, and water content were determined from syringe samples taken from the undisturbed center portion of split cores. The sample is taken by a modified 1 -cc pharmaceutical syringe in a manner similar to the process of piston coring. The syringe plunger is lowered to be flush with the syringe end, which has been shaped into a cutting edge whose diameter is the interior diameter of the syringe. The syringe is slowly forced into the sediment while the plunger is held at the material's surface. During Leg 27 the sediment was extruded from the syringe, and an interior section of about $0.4 \mathrm{cc}$ was used for the computations.

Volume measurements were made by the syringe scale (calibrated in 0.01-cc increments). The sample was weighed on a gimbal-mounted Kahn balance, then dried for 24 hours at $110^{\circ} \mathrm{C}$ and weighed again. Porosity, bulkwet density, and water content are determined since water weight, dry sediment weight, and sample volume are measured.

This test is limited in accuracy and range of material which may be sampled. It is useful only in the softer ooze and clay sediments, and becomes less accurate as sediment stiffens. A significant amount of sand-sized material in a sediment also reduces test accuracy. Sandsize grains are too large in comparison with syringe diameter for undisturbed syringe "coring." They tend to introduce air or water-filled voids along the syringe wall, resulting in inaccurately high porosity and low density. For the same reason, it is likely that the structure of a recovered sandy sediment is greatly disrupted and all such post-coring measurements are not representative of the in situ condition.

Accuracy of the measuring equipment during favorable sea conditions is estimated by Boyce (1973a) to be within $\pm 1 \%$ for each weighing measurement and within $\pm 4 \%$ for each volume measurement. Estimates of syringe precision vary between reported tests and likely reflect differences in sea conditions and sediments tested. During Leg 27, two syringe samples were taken adjacent to each other in 48 locations where sediment uniformity appeared excellent. Of these duplicate determinations, five were discarded due to apparent mismeasurements in one of the two syringes. The difference between the remaining determinations averaged $2.5 \%$ with a range of $0.2 \%-7.2 \%$. (Percentage here is computed as the absolute porosity difference divided by the average porosity of the two determinations.) In a similar study by von Huene et al., 1973), for Leg 23, porosity measurements on groups of duplicates showed a range of $10 \%$ and a standard deviation of $3 \%$. (Percentages quoted from von Huene refer to the absolute difference between the two porosity tests. Comparative values from the Leg 27 study would be a range of $4.5 \%$ and standard deviation of $1.2 \%$.) The better repetition in Leg 27 results may be indicative of more favorable sea conditions and finer-grained sediments tested during that cruise. (Weight and volume measurements for both studies were made by the same chemist.)

Precision of the syringe technique is different for each of the values of porosity, density, and water content. Porosity is determined from all three measurements of volume, wet weight, and dry weight and should, therefore, be the least accurate. Bulk density does not require the dry weight measurement, while water content does not require the volume measurement and is thus the most accurate.

\section{SOUND VELOCITY}

Compressional wave velocity measurements were made with the Hamilton Frame apparatus used on the Glomar Challenger since Leg 15. Measurements were made on relatively undisturbed materials which had been removed from the liner. In sections which were too soft for removal, velocity was measured through the split core liner, and applicable corrections for liner influence were applied. Some basalt specimens and consolidated sediment specimens were shaped for better transducer surface contact. The procedure for measuring acoustic velocity with the Hamilton Frame is detailed by Boyce (1973a).

\section{COMPARISON OF DENSITY DETERMINATIONS}

Of the five methods used to measure bulk-wet density during Leg 27, three can be considered to have important application for DSDP work. These are the GRAPE, syringe, and water-displacement methods. The other shipboard method, section weight determination, has no value to DSDP as a measure of density. The shore-laboratory method is not necessary except for use as a check on one of the other three. Each of the other three is a significant means for determining density. They have important differences as to the test accuracy, core area sampled, time required for the test, and limitations on use. Table 1 presents density data determined by these methods and at a shore laboratory under more stable conditions. Water content is included for a comparison of the syringe data with more accurate (larger volume) shore computations. (Although quantitative comparisons can be computed from the presented data, they have not been made in most instances because the sample size is not sufficiently large.)

Test accuracy varies considerably between the test methods. Accuracy of each of the test methods also varies, and is dependent on material-related conditions such as sediment type and stiffness. Syringe determinations must be considered the least accurate of the tests due to the small size of the sample. The weight and volume measurements cannot be made as accurately as can the measurements required by the other tests. In addition, during sampling the syringe may further disturb the sediment and introduce new inaccuracies. The test is also thought to be more dependent on individual technique than are the other tests. 
The GRAPE density determination has the potential for being reasonably accurate, but is dependent on the density of the sample, its mineralogy, and on how many gamma-ray counts are made per density measurement. Under any testing condition the accuracy is not likely to be better than the $1.5 \%-2.0 \%$ standard deviation of the $\mathrm{Ba}^{133}$ source obtained under conditions similar to the routine DSDP operating procedure. The theoretical errors and equipment precision is discussed in detail by Boyce (1973b). However, to obtain the highest degree of accuracy with sediment or rock that does not fill the core liner requires careful shipboard attention. After the core has been split the (printed) GRAPE trace should be examined so that diameter corrections can be made and slurry density measured. This amount of attention is not normally paid to the GRAPE data as it is extremely time consuming, and corrections must be approximated at a later date. Much published data are therefore less accurate than is possible with the GRAPE process. An advantage the GRAPE has over the other procedures is that it is made before the core is sectioned and before the disturbance which results from sectioning has been introduced.

The water-displacement method must be considered the most accurate bulk density measurement technique due to the simplicity of the test. The accuracy can be checked at any time by determining the density of an object whose density is known. (Standard deviation in density measurements made during Leg 27 on steel and brass objects was less than $0.21 \%$, as previously mentioned.) The accuracy appears significantly affected only by the volume of the material on which the test is made. Test sample volume should be kept above approximately $3 \mathrm{cc}$ of material or balance precision may affect the computation's third significant figure.

Each of the tests is made on a different quantity of material. The syringe samples only $0.2-0.4 \mathrm{cc}$ of sediment and is thus capable of discerning density variation over very short core distances. The sample is taken from the center of a split section and should contain only the least-disturbed material, that found away from the edge of the core liner. The sample volume for the water-displacement test is 10 to 100 times greater than the syringe volume, which limits the number of tests which can be made in a given area. This sample is also taken from the core center and should contain only the least-disturbed materials. Although the GRAPE requires a section length of only $1 \mathrm{~cm}$ for the instrumentation to reach a stable reading (in its normal mode of continuous operation), in practice a sediment layer must be considerably thicker to be displayed as a constant value on the reduced GRAPE output. Variation in material diameter or alternating layers of sediment require much additional attention to result in accurate GRAPE data. However, because GRAPE data are recorded for an entire core section, the density information is made available for future scientific study in areas which may not have been of interest to the shipboard staff. Density is determined by the other methods only at locations of interest to the shipboard scientists. The GRAPE also differs from the other methods in that it is a density average of the lessdisturbed material near the core center and the more highly disturbed material adjacent to the core liner.

The time required to perform each test is of critical importance in DSDP at-sea operation. Most testing while on site is limited by available time rather than by a limited desire for sampling by the scientific staff. The syringe sampling technique requires less than a minute to perform from the time the test location is made until the sealed sample is stored. Although this is only a fraction of the total time required for handling the syringe sample, it is the only time required while a split section is being sampled and described. This is most important. (The subsequent careful extruding, weighing, drying, reweighing, and syringe repreparation takes several hours per test and is normally done between sites when the chemist is free from other sampling duties.) The water-displacement technique uses more (split section) sampling time, perhaps 5 or 10 minutes, but requires no additional time beyond this. The GRAPE requires at least 16 minutes per core section. However, because the test is run on an unsplit section, this does not interfere directly with sampling done by the scientific staff. In addition, not all sections are GRAPE'd due to anticipated major distortion or when the rate of core arrival is exceptionally high (at shallow sites). Even so, GRAPE operations occupy far more onsite technician time. Post-cruise time and costs for reduction and presentation of the GRAPE data are considerable.

The syringe and water-displacement measurement techniques have limitations as to where each can be used. The syringe can only be used in the softest unconsolidated sediments which contain no coarse materials. Many of the stiffer clay and ooze sediments cannot be tested. (A possible problem with use of syringe samplers arises when stiff and softer sediments are interbedded in the same core. The syringe may be used only in the softest sediment. When the data are reviewed, the impression is left of a less dense profile than actually exists. Water-displacement density measurements can be made in any material which can be removed from the core liner and placed in water without disrupting its structure. Nearly all material recovered during Leg 27 could be tested this way. Only the softest ooze and sediments with a significant amount of silt or sand-size particles could not. The GRAPE equipment can be used on all materials recovered. Unfortunately, because the test is normally made before the core is split, it is often not apparent if the cored material is worth testing. After the core is split the test is more difficult to perform. The GRAPE data are also more difficult to obtain in some materials than in others. When basalt or lithified sediment is recovered, it normally does not fill the core liner and must be removed for testing in order to obtain the most accurate data. This complicates procedures of preparation, handling, and measurement for the GRAPE and requires much technician time. 


\section{REFERENCES}

Boyce, R. E., 1973a. Appendix I. Physical properties-methods. In Edgar, N. T., Saunders, J. B., et al., Initial Reports of the Deep Sea Drilling Project, Volume 15: Washington (U.S. Government Printing Office), p. 1115-1127.

Boyce, R. E., 1973b. DSDP Procedures using the Gamma Ray Attenuation Porosity Evaluator (GRAPE). Instructions for grain density, wet-bulk density, water content, and porosity determinations by individual samples and Gamma Ray Attenuation Porosity Evaluator. A DSDP instruction handbook: La Jolla (Scripps Institution of Oceanography) (revised January 1974).
Evans, H. B., 1965. GRAPE-A device for continuous determination of material density and porosity. SPWLA Logging Symp. 6th Ann. Trans., Dallas, Texas, v. 2, p. B1.

Harms, J. C. and Choquette, P. W., 1965. Geologic evaluation of a gamma-ray porosity device. SPWLA Logging Symp. 6th Ann. Trans., Dallas, Texas, v. 7, p. C1.

von Huene, R., Piper, O. J. W., and Duncan, J. Measurements of porosity in sediments of the Lower Continental Margin, Deep-Sea Fans, the Aleutian Trench, and Alaskan Abyssal Plain. In Kulm, L. D., von Huene, R., et al., Initial Reports of the Deep Sea Drilling Project, Volume 18: Washington (U.S. Government Printing Office), p. 1077. 
TABLE 1

Comparable Density and Water Content Determinations

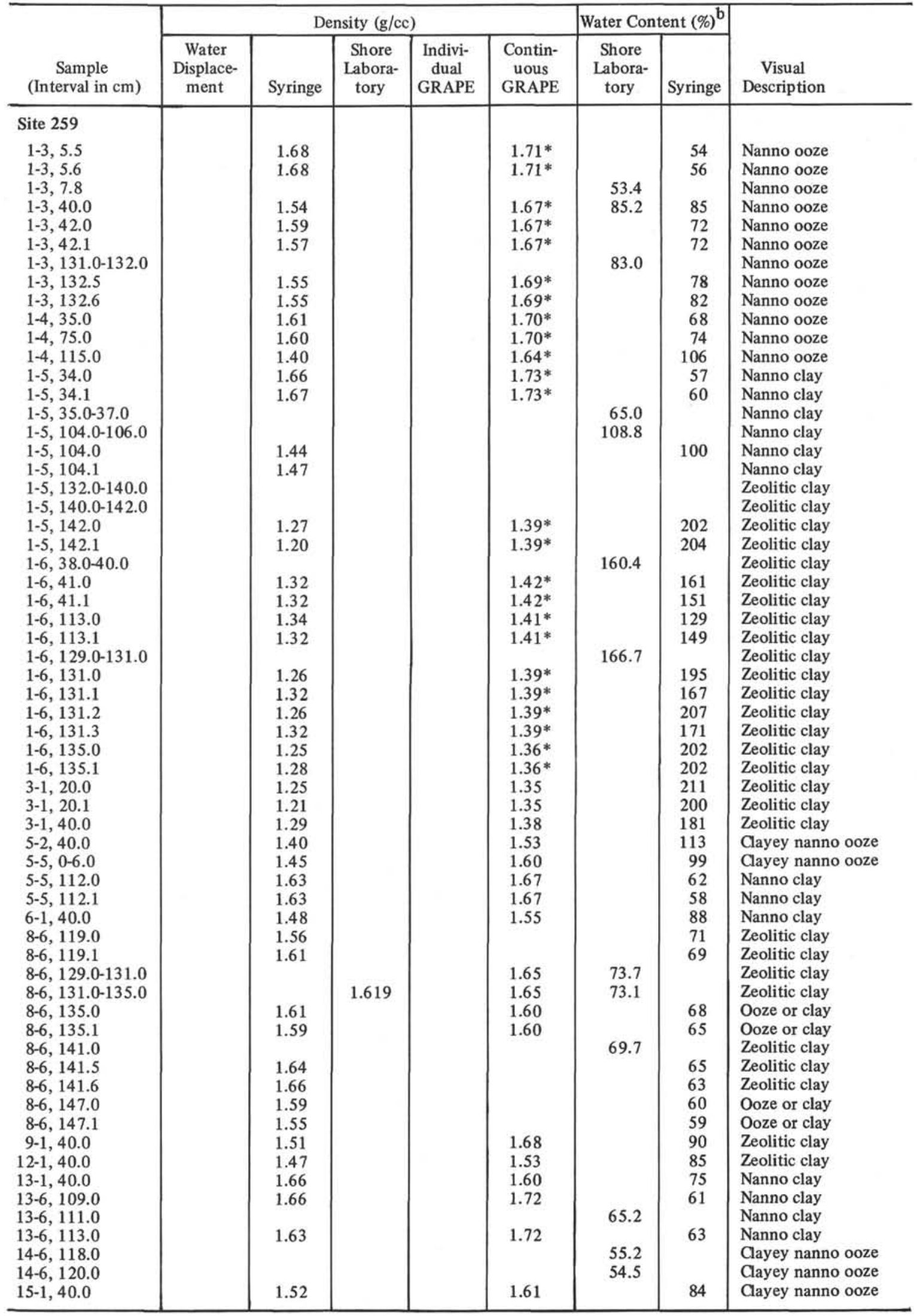


TABLE 1 - Continued

\begin{tabular}{|c|c|c|c|c|c|c|c|c|}
\hline \multirow[b]{2}{*}{$\begin{array}{c}\text { Sample } \\
\text { (Interval in cm) }\end{array}$} & \multicolumn{5}{|c|}{ Density $(\mathrm{g} / \mathrm{cc})$} & \multicolumn{2}{|c|}{ Water Content $(\%)^{\mathrm{b}}$} & \multirow[b]{2}{*}{$\begin{array}{c}\text { Visual } \\
\text { Description }\end{array}$} \\
\hline & $\begin{array}{c}\text { Water } \\
\text { Displace- } \\
\text { ment }\end{array}$ & Syringe & $\begin{array}{c}\text { Shore } \\
\text { Labora- } \\
\text { tory }\end{array}$ & $\begin{array}{c}\text { Indivi- } \\
\text { dual } \\
\text { GRAPE }\end{array}$ & $\begin{array}{l}\text { Contin- } \\
\text { uous } \\
\text { GRAPE }\end{array}$ & $\begin{array}{c}\text { Shore } \\
\text { Labora- } \\
\text { tory }\end{array}$ & Syringe & \\
\hline $\begin{array}{l}\text { Site 259- Con't. } \\
15-6,0-6 \\
16-4,131.0 \\
19-1,10.0 \\
19-2,113.0 \\
19-2,114.0 \\
19-2,122.5-123.5 \\
20-1,40.0 \\
20-4,82-86.0 \\
20-4,82.1-86.1 \\
21-3,107.5 \\
21-3,108.5 \\
21-3,109.0-114.0 \\
21-3,109.1-114.1 \\
23-1,113.0-114.0 \\
23-1,116.0-117.0 \\
23-3,131.0-134.0 \\
23-3,134.5-137.0 \\
23-3,137.5-138.5 \\
24-1,40.0 \\
25-1,40.0 \\
26-5,133.0-134.0 \\
26-5,137.0 \\
26-5,137.1 \\
27-1,44.0 \\
28-1,40.0 \\
28-2,121.0-128.0 \\
28-2,125.0-126.0 \\
28-2,141.0-142.0 \\
28-2,143.0-145.0 \\
31-1,40.0 \\
32-1,40.0 \\
32-2,114.0-117.0 \\
32-2,118.0-119.0 \\
32-2,122.0-123.0\end{array}$ & & $\begin{array}{l}1.66 \\
1.35 \\
1.59 \\
\\
1.56 \\
\\
1.60 \\
1.62\end{array}$ & $\begin{array}{l}1.682 \\
1.747\end{array}$ & & $\begin{array}{l}1.73 \\
1.75 \\
1.60 \\
1.70 \\
1.60 \\
\\
1.70 \\
1.70 \\
1.70 \\
1.69 \\
\\
1.62 \\
\\
1.69 \\
1.75 \\
\\
1.70 \\
1.70 \\
1.68 \\
1.74\end{array}$ & $\begin{array}{l}48.2 \\
74.7 \\
75.0 \\
73.3 \\
72.8 \\
\\
67.7 \\
67.6 \\
66.0 \\
64.2 \\
65.1 \\
66.2 \\
63.8 \\
\\
65.5\end{array}$ & $\begin{array}{l}59 \\
59 \\
\\
66 \\
62 \\
61 \\
60\end{array}$ & $\begin{array}{l}\text { Clayey nanno ooze } \\
\text { Clayey nanno ooze } \\
\text { Zeolitic clay } \\
\text { Zeolitic clay } \\
\text { Zeolitic clay } \\
\text { Zeolitic clay } \\
\text { Clay } \\
\text { Clay } \\
\text { Clay } \\
\text { Clay } \\
\text { Clay } \\
\text { Cay } \\
\text { Clay } \\
\text { Clay } \\
\text { Clay } \\
\text { Clay } \\
\text { Clay } \\
\text { Clay } \\
\text { Clay } \\
\text { Cay } \\
\text { Clay } \\
\text { Clay } \\
\text { Clay } \\
\text { Clay } \\
\text { Clay } \\
\text { Clay } \\
\text { Clay } \\
\text { Clay } \\
\text { Cay } \\
\text { Clay } \\
\text { Clay } \\
\text { Cay } \\
\text { Clay } \\
\text { Clay }\end{array}$ \\
\hline $\begin{array}{l}\text { Site } 260 \\
1-1,13.5 \\
1-1,15.5 \\
1-1,62.0 \\
1-1,64.5 \\
1-1,80.0 \\
1-2,50.0 \\
1-2,53.0 \\
1-2,106.5 \\
1-2,106.6 \\
1-2,109.0 \\
1-2,109.5 \\
1-3,12.0 \\
1-3,14.0 \\
1-3,45.5 \\
1-3,136.5 \\
1-3,139.0 \\
1-4,0-6.0 \\
1-4,0.1-6.1 \\
1-4,0.2-6.2 \\
2-2,67.0 \\
2-2,69.0 \\
2-2,88.0 \\
2-2,89.5 \\
2-2,130.5 \\
2-2,131.0-133.0 \\
2-2,134.0 \\
2-3,0-6.0 \\
3-1,137.5-139.5 \\
3-1,140.0 \\
3-4,109.0\end{array}$ & & $\begin{array}{l}1.20 \\
1.22 \\
1.22 \\
1.19 \\
1.11 \\
1.24 \\
1.22 \\
1.24 \\
1.26 \\
1.21 \\
1.28 \\
1.21 \\
1.21 \\
1.20 \\
1.27 \\
1.24 \\
1.25 \\
1.23 \\
\\
1.73 \\
1.65 \\
1.69 \\
1.65 \\
1.47 \\
\\
1.42 \\
1.54 \\
1.47 \\
1.90\end{array}$ & 1.468 & & $\begin{array}{l}1.39^{*} \\
1.41^{*} \\
1.34^{*} \\
1.34^{*} \\
1.35^{*} \\
1.35^{*} \\
1.35^{*} \\
1.39^{*} \\
1.39^{*} \\
1.39^{*} \\
1.39^{*} \\
1.40^{*} \\
1.40^{*} \\
1.39^{*} \\
1.32^{*} \\
1.32^{*} \\
1.31^{*} \\
1.31^{*} \\
1.82 \\
1.82 \\
1.80 \\
1.80 \\
1.75 \\
1.75 \\
1.75 \\
1.82 \\
1.56 \\
1.56 \\
1.86\end{array}$ & 106.4 & $\begin{array}{r}260 \\
270 \\
244 \\
241 \\
313 \\
269 \\
257 \\
236 \\
207 \\
245 \\
207 \\
257 \\
261 \\
272 \\
206 \\
198 \\
220 \\
215 \\
226 \\
52 \\
60 \\
55 \\
63 \\
47 \\
\\
56 \\
47 \\
\\
\\
\\
37\end{array}$ & $\begin{array}{l}\text { Nanno ooze } \\
\text { Nanno ooze } \\
\text { Radiolarian ooze } \\
\text { Radiolarian ooze } \\
\text { Nanno ooze } \\
\text { Radiolarian ooze } \\
\text { Radiolarian ooze } \\
\text { Radiolarian ooze } \\
\text { Radiolarian ooze } \\
\text { Radiolarian ooze } \\
\text { Radiolarian ooze } \\
\text { Radiolarian ooze } \\
\text { Radiolarian ooze } \\
\text { Radiolarian ooze } \\
\text { Radiolarian clay } \\
\text { Radiolarian clay } \\
\text { Radiolarian clay } \\
\text { Radiolarian clay } \\
\text { Radiolarian clay } \\
\text { Nanno ooze } \\
\text { Nanno ooze } \\
\text { Nanno ooze } \\
\text { Nanno ooze } \\
\text { Foram nanno ooze } \\
\text { Foram nanno ooze } \\
\text { Foram nanno ooze } \\
\text { Foram nanno ooze } \\
\text { Nanno clay } \\
\text { Nanno clay } \\
\text { Nanno clay }\end{array}$ \\
\hline
\end{tabular}


TABLE 1 - Continued

\begin{tabular}{|c|c|c|c|c|c|c|c|c|}
\hline \multirow[b]{2}{*}{$\begin{array}{c}\text { Sample } \\
\text { (Interval in } \mathrm{cm} \text { ) }\end{array}$} & \multicolumn{5}{|c|}{ Density $(g / c c)$} & \multicolumn{2}{|c|}{ Water Content $(\%)^{\mathrm{b}}$} & \multirow[b]{2}{*}{$\begin{array}{c}\text { Visual } \\
\text { Description }\end{array}$} \\
\hline & $\begin{array}{c}\text { Water } \\
\text { Displace- } \\
\text { ment }\end{array}$ & Syringe & $\begin{array}{l}\text { Shore } \\
\text { Labora- } \\
\text { tory }\end{array}$ & $\begin{array}{c}\text { Indivi- } \\
\text { dual } \\
\text { GRAPE }\end{array}$ & $\begin{array}{l}\text { Contin- } \\
\text { uous } \\
\text { GRAPE }\end{array}$ & $\begin{array}{c}\text { Shore } \\
\text { Labora- } \\
\text { tory }\end{array}$ & Syringe & \\
\hline $\begin{array}{l}\text { Site } 260 \text { - Con't. } \\
3-4,110.0 \\
3-5,110.0 \\
3-5,112.0 \\
3-5,112.0-114.0 \\
3-5,115.0 \\
3-5,117.0 \\
3-6,0-6.0 \\
4-1,44.0 \\
5-6,106.5-110.0 \\
5-6,110.0 \\
5-6,112.0 \\
7-2,100.0 \\
7-2,102.0 \\
7-3,47.0 \\
7-3,49.0 \\
7-4,19.0 \\
7-4,20.5 \\
8-6,40.0 \\
8-6,42.0 \\
8-6,59.0 \\
8-6,59.1 \\
8-6,85.0 \\
8-6,87.0 \\
8-6,110.0 \\
8-6,112.0 \\
11-1,84.0-86.0 \\
11-1,126.0-131.0 \\
12-2,24.0-26.0 \\
12-2,75.0-77.0 \\
13-1,1.0-3.0 \\
15-3,108.0-110.0 \\
16-2,42.0-45.0 \\
17-1,88.0-93.0 \\
18-2,69.5-72.5\end{array}$ & $\begin{array}{l}1.864 \\
1.940 \\
1.802 \\
1.919 \\
1.818 \\
1.637 \\
1.614 \\
1.873 \\
1.719\end{array}$ & $\begin{array}{l}1.86 \\
1.74 \\
1.76 \\
\\
1.73 \\
1.73 \\
1.54 \\
1.52 \\
\\
1.71 \\
1.68 \\
1.52 \\
1.63 \\
1.66 \\
1.60 \\
1.61 \\
1.58 \\
1.65 \\
1.56 \\
1.72 \\
1.60 \\
1.62 \\
1.68 \\
1.62 \\
1.64\end{array}$ & 1.671 & $\begin{array}{l}1.918 \\
1.849 \\
1.877 \\
1.953 \\
1.888 \\
1.687 \\
1.743 \\
1.925 \\
1.832\end{array}$ & $\begin{array}{l}1.86 \\
1.84 \\
1.84 \\
1.84 \\
1.84 \\
1.84 \\
1.70 \\
1.50 \\
1.72 \\
1.72 \\
1.72 \\
1.68 \\
1.68 \\
1.70 \\
1.70 \\
\\
\\
1.72 \\
1.72 \\
1.70 \\
1.70 \\
1.76 \\
1.76 \\
1.70 \\
1.70 \\
1.80 \\
1.75\end{array}$ & $\begin{array}{l}51.5 \\
61.0\end{array}$ & $\begin{array}{l}38 \\
48 \\
47 \\
\\
50 \\
51 \\
\\
89 \\
\\
54 \\
55 \\
60 \\
65 \\
52 \\
53 \\
55 \\
55 \\
54 \\
54 \\
51 \\
54 \\
52 \\
50 \\
55 \\
55\end{array}$ & $\begin{array}{l}\text { Nanno ooze } \\
\text { Foram nanno ooze } \\
\text { Foram nanno ooze } \\
\text { Foram nanno ooze } \\
\text { Foram nanno ooze } \\
\text { Foram nanno ooze } \\
\text { Foram nanno ooze } \\
\text { Cay } \\
\text { Nanno clay } \\
\text { Nanno clay } \\
\text { Nanno clay } \\
\text { Zeolitic clay } \\
\text { Zeolitic clay } \\
\text { Zeolitic clay } \\
\text { Zeolitic clay } \\
\text { Zeolitic clay } \\
\text { Zeolitic clay } \\
\text { Zeolitic clay } \\
\text { Zeolitic clay } \\
\text { Zeolitic clay } \\
\text { Zeolitic clay } \\
\text { Zeolitic clay } \\
\text { Zeolitic clay } \\
\text { Zeolitic clay } \\
\text { Zeolitic clay } \\
\text { Nanno ooze } \\
\text { Chalk } \\
\text { Chalk } \\
\text { Claystone } \\
\text { Chalk } \\
\text { Clay } \\
\text { Clay } \\
\text { Nanno clay } \\
\text { Radiolarian clay }\end{array}$ \\
\hline $\begin{array}{l}\text { Site } 261 \\
3-1,115.5 \\
3-1,116.5 \\
3-2,0-10.0 \\
3-2,14.5 \\
3-2,65.0 \\
3-2,103.5 \\
3-4,8.5 \\
3-4,15.0 \\
3-4,37.0 \\
3-4,40.5 \\
3-4,57.0 \\
3-4,65.5 \\
3-4,83.5 \\
3-4,92.5 \\
3-4,106.5 \\
3-4,108.5 \\
3-4,113.0 \\
3-4,121.5 \\
6-1,40.0 \\
6-5,0-6.0 \\
6-5,0-6.0 \\
8-6,33.0 \\
8-6,37.0 \\
8-6,54.5-57.5 \\
8-6,56.0 \\
8-6,61.0 \\
8-6,111.0 \\
8-6,144.0 \\
20-2,116.0-119.0 \\
20-2,133.0-136.0 \\
21-2,38.0-42.0\end{array}$ & $\begin{array}{l}1.948 \\
1.910 \\
1.838\end{array}$ & $\begin{array}{l}1.49 \\
1.48 \\
1.60 \\
1.61 \\
1.61 \\
1.61 \\
1.43 \\
1.44 \\
1.58 \\
1.60 \\
1.64 \\
1.66 \\
1.45 \\
1.46 \\
1.61 \\
1.60 \\
1.61 \\
1.67 \\
1.61 \\
1.67 \\
1.67 \\
1.69 \\
1.70 \\
1.71 \\
1.69 \\
1.70 \\
1.73\end{array}$ & & & $\begin{array}{l}1.65 \\
1.65 \\
1.67 \\
1.70 \\
1.54 \\
1.56 \\
1.67 \\
1.67 \\
1.71 \\
1.70 \\
1.56 \\
1.56 \\
1.70 \\
1.70 \\
1.74 \\
1.75 \\
1.60 \\
1.70 \\
1.70 \\
1.73 \\
1.73 \\
1.75 \\
1.75 \\
1.76 \\
1.76 \\
1.98 * \\
1.92 * \\
1.83 *\end{array}$ & 56.3 & $\begin{array}{r}100 \\
97 \\
70 \\
70 \\
69 \\
71 \\
108 \\
105 \\
74 \\
74 \\
61 \\
63 \\
106 \\
103 \\
69 \\
69 \\
67 \\
56 \\
63 \\
59 \\
59 \\
51 \\
53 \\
\\
51 \\
52 \\
54 \\
51\end{array}$ & $\begin{array}{l}\text { Cay } \\
\text { Cay } \\
\text { Nanno ooze } \\
\text { Nanno ooze } \\
\text { Nanno ooze } \\
\text { Nanno ooze } \\
\text { Clay } \\
\text { Clay } \\
\text { Nanno ooze } \\
\text { Nanno ooze } \\
\text { Nanno ooze } \\
\text { Nanno ooze } \\
\text { Clay } \\
\text { Cay } \\
\text { Nanno ooze } \\
\text { Nanno ooze } \\
\text { Nanno ooze } \\
\text { Nanno ooze } \\
\text { Cay } \\
\text { Cay } \\
\text { Cay } \\
\text { Zeolitic clay } \\
\text { Zeolitic clay } \\
\text { Zeolitic clay } \\
\text { Zeolitic clay } \\
\text { Zeolitic clay } \\
\text { Zeolitic clay } \\
\text { Zeolitic clay } \\
\text { Caystone } \\
\text { Caystone } \\
\text { Hard clay }\end{array}$ \\
\hline
\end{tabular}


TABLE 1 - Continued

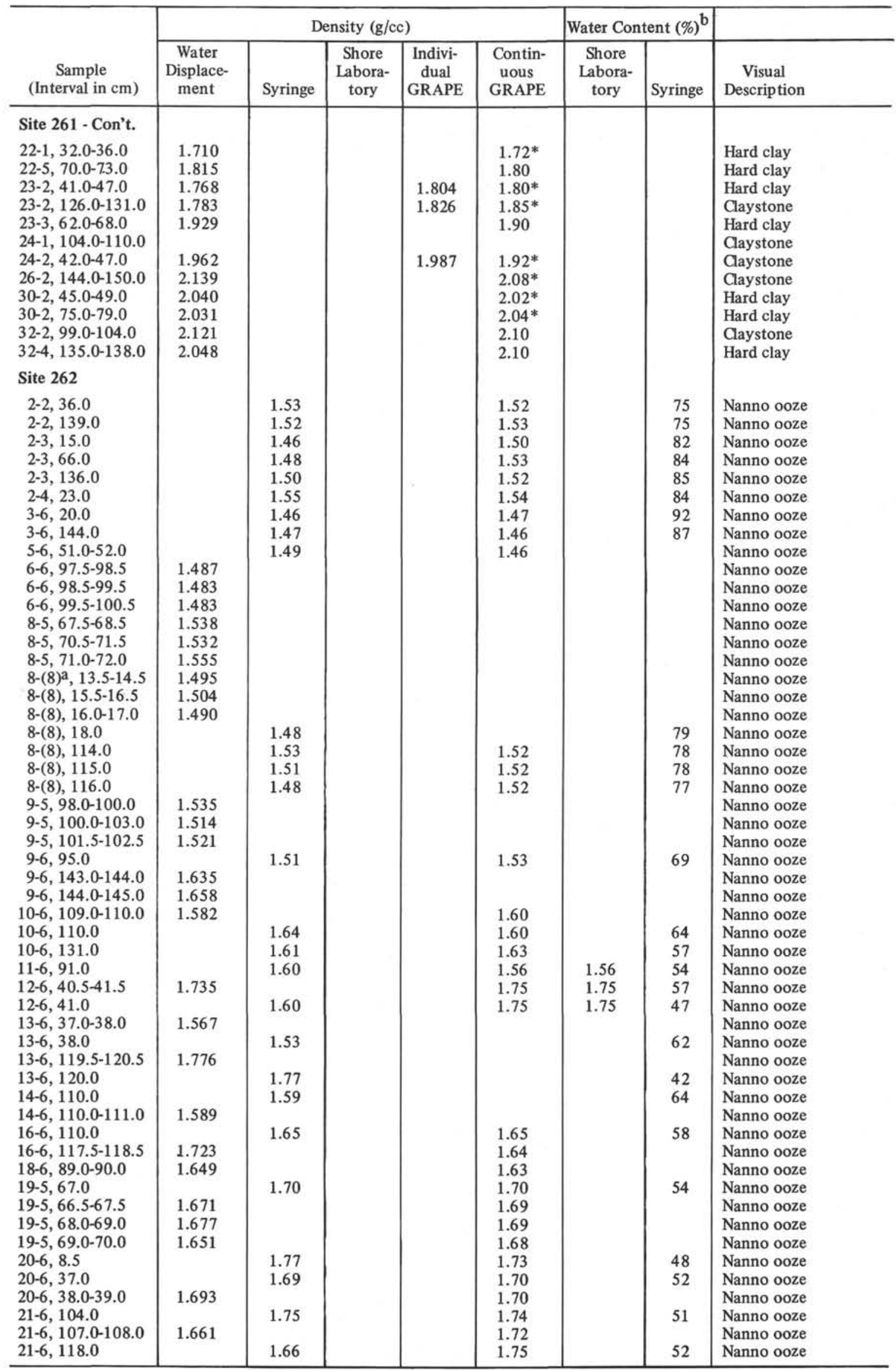


TABLE 1 - Continued

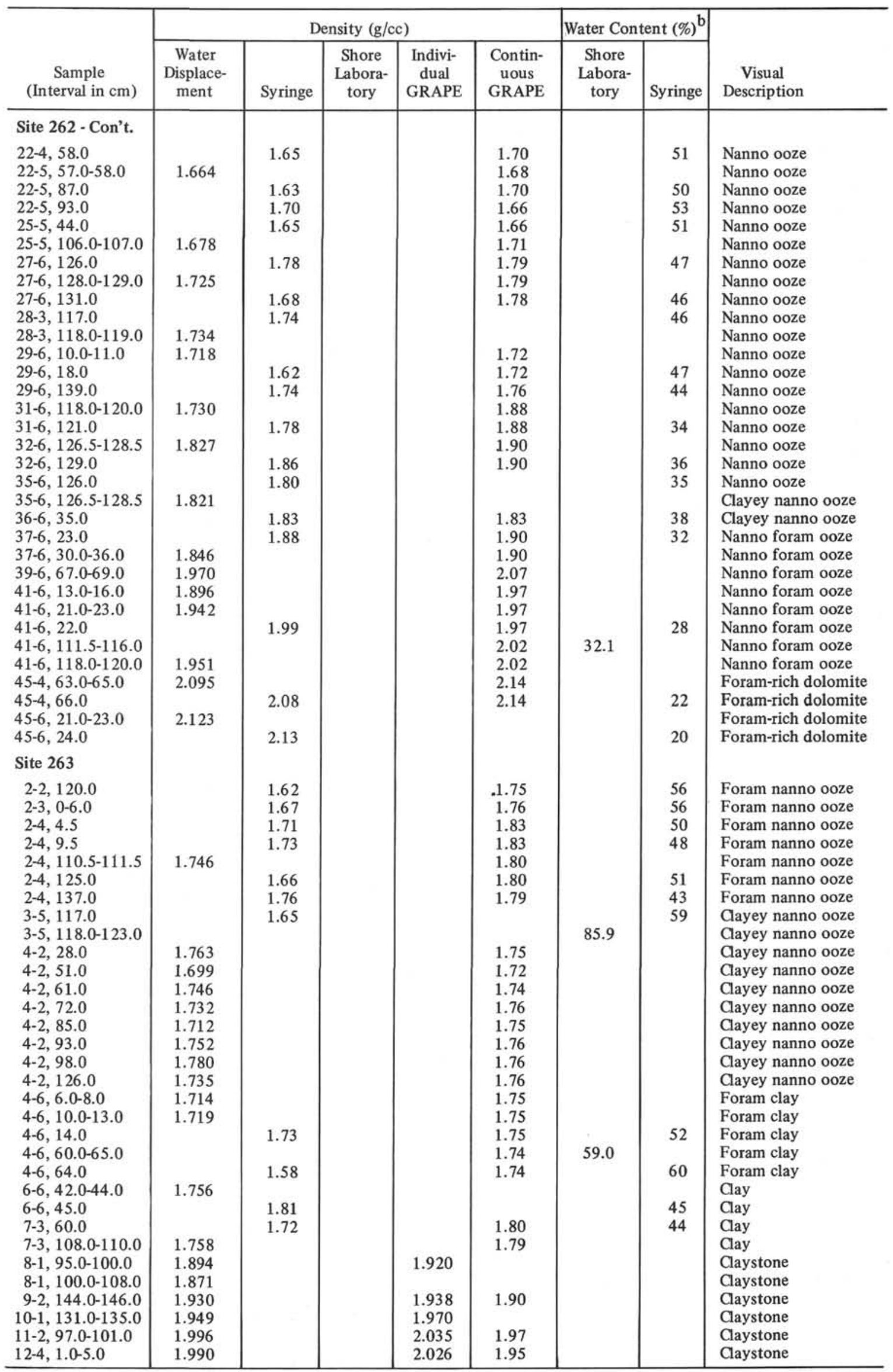


TABLE 1 - Continued

\begin{tabular}{|c|c|c|c|c|c|c|c|c|}
\hline \multirow[b]{2}{*}{$\begin{array}{c}\text { Sample } \\
\text { (Interval in } \mathrm{cm} \text { ) }\end{array}$} & \multicolumn{5}{|c|}{ Density $(\mathrm{g} / \mathrm{cc})$} & \multicolumn{2}{|c|}{ Water Content $(\%)^{\mathrm{b}}$} & \multirow[b]{2}{*}{$\begin{array}{c}\text { Visual } \\
\text { Description }\end{array}$} \\
\hline & $\begin{array}{c}\text { Water } \\
\text { Displace- } \\
\text { ment }\end{array}$ & Syringe & $\begin{array}{l}\text { Shore } \\
\text { Labora- } \\
\text { tory }\end{array}$ & $\begin{array}{l}\text { Indivi- } \\
\text { dual } \\
\text { GRAPE }\end{array}$ & $\begin{array}{l}\text { Contin- } \\
\text { uous } \\
\text { GRAPE }\end{array}$ & $\begin{array}{c}\text { Shore } \\
\text { Labora- } \\
\text { tory }\end{array}$ & Syringe & \\
\hline \multicolumn{9}{|l|}{ Site 263 - Con't. } \\
\hline $13-6,55.0-60.0$ & 2.021 & & & 1.863 & 2.04 & & & Claystone \\
\hline $14-3,37.0-42.0$ & 1.974 & & & 1.993 & $1.89 *$ & & & Claystone \\
\hline $15-3,41.0-45.0$ & 1.992 & & & 2.039 & 2.00 & & & Claystone \\
\hline $16-1,114.0-118.0$ & 2.053 & & & 2.097 & & & & Claystone \\
\hline $17-5,128.0-133.0$ & 2.031 & & & 2.069 & $1.95^{*}$ & & & Claystone \\
\hline $18-4,103.0-107.0$ & 2.072 & & & 2.103 & $1.94 *$ & & & Claystone \\
\hline $19-4,93.0-95.0$ & 2.088 & & & 2.135 & & & & Claystone \\
\hline $19-4,95.0-97.0$ & 2.078 & & & 2.157 & & & & Claystone \\
\hline $20-5,42.0-46.0$ & 2.076 & & & 2.132 & & & & Claystone \\
\hline $21-4,47.0-51.0$ & 2.128 & & & 2.163 & & & & Claystone \\
\hline $22-2,15.0-19.0$ & 2.524 & & & 2.550 & & & & Limestone \\
\hline $22-2,38.0-42.0$ & 2.572 & & & 2.589 & & & & Limestone \\
\hline $22-3,8.0-11.0$ & 2.148 & & & 2.213 & & & & Claystone \\
\hline $23-3,109.0-114.0$ & 2.203 & & & 2.211 & & & & Claystone \\
\hline $23-4,48.0-51.0$ & 3.161 & & & 3.190 & & & & Dolomite with calcite \\
\hline $24-3,123.0-127.0$ & 2.190 & & & 2.245 & & & & Claystone \\
\hline $25-3,66.0-69.0$ & 2.592 & & & 2.703 & & & & Limestone \\
\hline $25-3,67.0$ & 2.570 & & & & & & & Limestone \\
\hline $25-3,104.0-108.0$ & 2.273 & & & 2.353 & $2.15^{*}$ & & & Claystone \\
\hline $25-4,99.0-103.0$ & 2.242 & & & 2.326 & $2.12 *$ & & & Claystone \\
\hline $26-4,136.0-140.0$ & 2.208 & & & 2.240 & & & & Claystone \\
\hline $28-3,50.0-54.0$ & 2.219 & & & 2.267 & & & & Caystone \\
\hline $29-4,27.0-31.0$ & 2.238 & & & 2.274 & & & & Claystone \\
\hline
\end{tabular}

Note: Asterisk denotes GRAPE data having been corrected to adjust for a sample diameter which is smaller than the standard core liners inside dimension.

${ }^{a}$ Section 8 refers to the lowest section from Core 8 , which is not described in the core summary. Gas expansion pushed apart plugs of sediments, resulting in the recovery of two additional cores of sediment.

${ }^{b}$ Water content is defined as the weight of water in the sediment divided by the weight of the saturated wet sediment and expressed as a percentage. 